\title{
Chemical and botanical characterization of Chilean propolis and biological activity on cariogenic bacteria Streptococcus mutans and Streptococcus sobrinus
}

\author{
Leticia Barrientos ${ }^{1,2}$, Christian L. Herrera ${ }^{1}$, Gloria Montenegro ${ }^{3}$, Ximena Ortega ${ }^{3}$, \\ Jorge Veloz ${ }^{1}$, Marysol Alvear ${ }^{4}$, Alejandro Cuevas ${ }^{1}$, Nicolás Saavedra ${ }^{1}$, \\ Luis A. Salazar ${ }^{1,2}$ \\ ${ }^{1}$ Centro de Biología Molecular \& Farmacogenética, Scientific and Technological Bioresource Nucleus, \\ Universidad de La Frontera, Temuco, Chile. \\ ${ }^{2}$ Centro de Excelencia en Estudios Genéticos e Inmunológicos, Universidad de La Frontera, \\ Temuco, Chile. \\ ${ }^{3}$ Departamento de Ciencias Vegetales, Facultad de Agronomía e Ingeniería Forestal, \\ Pontificia Universidad Católica de Chile, Santiago, Chile. \\ ${ }^{4}$ Departamento de Ciencias Químicas y Recursos Naturales, \\ Facultad de Ingeniería, Ciencias y Administración, Universidad de La Frontera, Temuco, Chile.
}

Submitted: June 2, 2012; Approved: September 10, 2012.

\begin{abstract}
Propolis is a non-toxic natural substance with multiple pharmacological properties including anticancer, antioxidant, fungicidal, antibacterial, antiviral, and anti-inflammatory among others. The aim of this study was to determine the chemical and botanical characterization of Chilean propolis samples and to evaluate their biological activity against the cariogenic bacteria Streptococcus mutans and Streptococcus sobrinus. Twenty propolis samples were obtained from beekeeping producers from the central and southern regions of Chile. The botanical profile was determined by palynological analysis. Total phenolic contents were determined using colorimetric assays. Reverse phase HPLC and HPLC-MS were used to determine the chemical composition. The minimum inhibitory concentration (MIC) was determined on S. mutans and S. sobrinus. All propolis samples were dominated by structures from native plant species. The characterization by HPLC/MS, evidenced the presence of quercetin, myricetin, kaempferol, rutine, pinocembrin, coumaric acid, caffeic acid and caffeic acid phenethyl ester, that have already been described in these propolis with conventional HPLC. Although all propolis samples inhibited the mutans streptococci growth, it was observed a wide spectrum of action (MIC 0.90 to $8.22 \mu \mathrm{g} \mathrm{mL}^{-1}$ ). Given that results it becomes increasingly evident the need of standardization procedures, where we combine both the determination of botanical and the chemical characterization of the extracts. Research conducted to date, describes a promising effectiveness of propolis in the prevention of caries and other diseases of the oral cavity, making it necessary to develop studies to identify and understand the therapeutic targets or mechanisms of molecular action of the various compounds present on them.
\end{abstract}

Key words: propolis, botanical characterization, chemical characterization, Streptococcus mutans, Streptococcus sobrinus.

\section{Introduction}

Among the natural products that have received attention recently, we draw attention on propolis, a resinous sub- stance collected by bees (Apis mellifera) from buds, shoots and wounds of various plant species and mixed with mandible secretions for use in construction, maintenance and protection of their hives (Burdock, 1998). It has over 300

Send correspondence to L.A. Salazar. Centro de Biología Molecular \& Farmacogenética, Scientific and Technological Bioresource Nucleus, Universidad de La Frontera, Av. Francisco Salazar 01145, Casilla 54-D, Temuco, Chile. E-mail: luis.salazar@ufrontera.cl. 
compounds, among which polyphenols (flavonoids, phenolic acids and their esters), terpenoids, steroids, sugars and amino acids have been detected in raw propolis, but its composition is qualitatively and quantitatively variable, depending on the vegetation at the site from which it was collected and the collection season (Koo et al., 1999; Bankova, 2005; Tosi et al., 2007; Valencia et al., 2012). The main constituents of propolis in Europe, China, and North America are flavonoids and phenolic acid esters (Bankova et al., 2000; Chen et al., 2004; Lotti et al., 2010). Brazilian propolis contains, principally, diterpenes, lignans, $p$-coumaric acid derivatives, sesquiterpenes and acetophenones (Bankova, 2005; Piccinelli et al., 2005).

Propolis is a non-toxic natural substance with multiple pharmacological properties including cytostatic, hepato-protective, antioxidant and anti-inflammatory (Burdock, 1998; Kujumgiev et al., 1999; Borrelli et al., 2002; Russo et al., 2002). It is also considered as an alternative in the treatment and prevention of many infectious diseases, since it displays a wide range of antimicrobial activity against a variety of bacteria, fungi, parasites and virus (Bankova et al., 1995; Kujumgiev et al., 1999; Sforcin et al., 2000; Orsi et al., 2005). Due to this wide range of biological activities, propolis is used in food industry, cosmetology, and complementary medicine products. These observations emphasize the need to extend our knowledge about the chemical and biological characterization of propolis, which would aid with the appropriate use of this natural product in human health (Valencia et al., 2012).

Dental caries are known to be one of the most prevalent and costly oral infectious diseases worldwide (Dye et al., 2007); it is a multifactorial infectious disease in which diet, nutrition, microbial infection, and host response all play important roles. Dental plaque is a typical bacterial biofilm that contains mutans streptococci and other oral bacteria and their products. Among them, Streptococcus mutans and $S$. sobrinus have been recognized to be the mayor causative agent of dental caries in humans (Loesche, 1986; Smith, 2002).

Some naturals compounds based in tea (HamiltonMiller, 2001), cranberries (Steinberg et al., 2004), cacao (Osawa et al., 2001), herbal extracts (Limsong et al., 2004) and propolis (Bankova et al., 1995; Koo et al., 2000, 2002a, 2002b; Duarte et al., 2006;), have shown inhibition of biofilm and caries development in some species of mutans streptococci, being propolis and its polyphenolic compounds, the most studied. The biofilm formation is vital for the progression of dental caries and thus, inhibition of this factor is one of the strategies currently used to prevent this disease (Xiao et al., 2007).

In view of the foregoing considerations the aim of the present study was to determine both the chemical and botanical characterization and to determine the biological activity on mutans streptococci of 20 propolis samples obtained in central and southern Chile.

\section{Materials and Methods}

\section{Preparation of ethanolic and methanolic extracts of propolis (EEP)}

Twenty propolis samples were obtained from various beekeeping producers from the central and southern region (Valparaíso, Metropolitana, Libertador Bernardo O’Higgins and La Araucanía Regions), Chile.

Concentrated ethanol and methanol extracts (EEP) were prepared with $30 \mathrm{~g}$ of chopped fresh propolis, which were macerated for 7 days at room temperature, covered with ethanol $(70 \%)$ in volumetric flask $(100 \mathrm{~mL})$ and stirred occasionally, every day, and finally, filtered with Whatman paper $\mathrm{N}^{\circ} 2$. The methanolic extracts were centrifuged three times to remove waxes. All the extracts were stored in the dark at $-20{ }^{\circ} \mathrm{C}$ until analysis.

\section{Botanical analysis of propolis}

For this determination was used the methodology described by Montenegro et al. (1992). Subsequently, were counted and identified plant structures (pollen grains, trichomes and vessels). The identification was made by comparing the different structures with relevant literature (Heusser, 1971; Montenegro, 1984; Erdtman, 1986), with photographs and permanent preparations available in the Laboratory of Botany (Department of Plant Sciences, Faculty of Agronomy and Forest Engineering, Pontificia Universidad Católica de Chile, Santiago, Chile), and the proportion of each of the total structures counted were estimated.

\section{Determination of total phenolic content}

Total phenolic content of propolis extracts was determined by colorimetric assays using the Folin-Ciocalteu method (Singleton et al., 1999), with modifications. Each extract was diluted 1:10 in ethanol $70 \%$ and then 1:10 in distilled water; then $40 \mu \mathrm{L}$ of this dilution was mixed with $560 \mu \mathrm{L}$ of distilled water, $100 \mu \mathrm{L}$ of Folin-Ciocalteu reagent (Merck, Germany) and $300 \mu \mathrm{L}$ sodium carbonate $7.5 \%(\mathrm{w} / \mathrm{v})$. The absorbance was measured at $760 \mathrm{~nm}$ after $2 \mathrm{~h}$ incubation at room temperature. The concentrations were calculated from a calibration curve and were expressed in $\mathrm{mg} / \mathrm{mL}$ equivalent to the standard catechin.

\section{Chemical characterization of a propolis extract}

High performance liquid chromatographic (HPLC) analysis was made on an HPLC system (Merck-Hitachi model L-4200) equipped with a pump (model L-6200), a UV-visible detector and a Sphere Column Heater (Phenomenex Terma model TS-130). The separation was made in an RP-18 column $(12.5 \times 0.4 \mathrm{~cm}$, particle size $5 \mu \mathrm{m})$ (Merck, Germany), 149 which separates at $25^{\circ} \mathrm{C}$ using a mixture of formic acid 5\% in water (A) and methanol (B) as mobile phase. The separation of the compounds was carried out by an isocratic-0 to 10 min-run, with the mixture $70 \% \mathrm{~A}$ 
and $30 \% \mathrm{~B}$, followed by a gradient up to $100 \% \mathrm{~B}$ at $70 \mathrm{~min}$. The compounds were detected at $290 \mathrm{~nm}$, with 0.001 sensitivity; the injection volume was $10 \mu \mathrm{L}$. The identification of the phenolic compounds was made using the following standards: myricetin, kaempferol, quercetin, caffeic acid, galangin, pinocembrin, apigenin, caffeic acid phenethyl ester (CAPE) and resveratrol (Sigma, USA).

The analysis of the methanolic extract of propolis was performed on a LC-MS MS system, consisting of a liquid chromatograph (Shimadzu, Japan) connected to MDS Sciex Mass Spectrometer QTRAP 3200 (Applied Biosystems, USA). Chromatographic separation was performed with a RP-C18 Column Inertsil ODS-3 $(2.1 \times 150 \mathrm{~mm}$, $3 \mathrm{~mm}$ ). The elution was performed at $35^{\circ} \mathrm{C}$ using as solvent A, $0.1 \%$ formic acid and solvent $\mathrm{B}$, methanol. Data acquisition was performed using the software Analyst 1.5.1 (Applied Biosystems, USA). Flavonols were studied in both positive and negative polarity. The specific parameters for the MRM experiment (Multiple Reaction Monitoring) in positive and negative polarity were optimized using standards myricetin, quercetin, rutin and kaempferol by direct injection method.

\section{Biological action of propolis on cariogenic bacteria}

S. mutans and S. sobrinus were clinical samples obtained from children of La Araucanía Region isolated in a previous study and confirmed by PCR-RFLP (Salazar et al., 2008).

The minimum inhibitory concentration (MIC) was performed as described by the Clinical and Laboratory Standards Institute guidelines (2007) by microdilution methodology, which involves making serial dilutions of the compound to be studied on microplates (96 wells) with tryptic soy broth. The starting inoculum was $5 \times 10^{5}$ $\mathrm{cfu} / \mathrm{mL}$. The MIC was determined in triplicate for each propolis against bacterial strains isolated, and was evaluated after $48 \mathrm{~h}$ of incubation at $37^{\circ} \mathrm{C}$, as the lowest concentration that completely inhibited the formation of visible growth.

\section{Statistical analysis}

The analysis of the data was performed using the program GraphPad Prism, version 5.0 (U.S.). When necessary we calculated averages, standard deviations, maximum and minimum values. ANOVA was used for comparisons of the antimicrobial activity of propolis. Comparisons between samples (in triplicate) were performed with Dunnett's Multiple Comparison Test. The statistical significance level considered was $\mathrm{p} \leq 0.05$.

\section{Results}

\section{Botanical analysis of propolis}

The fraction of plant debris in the samples of propolis from the central region (samples P001 to P012), were domi- nated by structures from native plant species, highlighting the contribution of Trevoa quinquenervia, Aristotelia chilensis (maqui), Lithrea caustica (litre), Retanilla trinervia (tebo), Quillaja saponaria (quillay), and species of the genus Escallonia. Of these species, the leading producers of resins are litre, tevo and species of the genus Escallonia. In samples from Southern Chile (samples P013 to P020), the fraction of plant debris was mostly dominated by pollen of the species Lotus uliginosus (alfalfa chilota) and structures from native plants, mostly trees or shrubs, such as Aextoxicon punctatum (olivillo), Baccharis linearis (romerillo) and Eucryphia cordifolia (ulmo) (Table 1).

It should be noted, in all samples, the almost total absence of structures from introduced species in the area and that are large producers of resins, such as forest trees of the genera Eucalyptus and Pinus. There were no structures of the genus Populus.

\section{Total phenolic content}

Total phenolic content of propolis extracts was determined by colorimetric assays using the Folin-Ciocalteu method. The results obtained indicate the presence of polyphenolic compounds, in varying concentrations, and these results are similar to those described by other studies from our laboratory (Table 2).

\section{Chemical characterization of propolis}

The HPLC chromatographic profiles of all propolis samples looked very similar. The main peaks in the chromatograms were identified using standard samples. The different samples of propolis studied show varying concentrations of caffeic acid, myricetin, quercetin, kaempferol, apigenin, pinocembrin, CAPE and galangin (Tables 3 and 4). Further results from the chemical characterization of propolis analyzed by LC-MS using the MRM program in positive and negative polarity, confirm in the propolis samples, the presence of the same compounds and others like rutine (propolis from La Araucanía Region), that were not detected with conventional HPLC. Particularly, this method recognizes the presence or absence of compounds according to retention times made equal to the sample from a standard. Figures 1 and 2 show the flavonols and phenolic acids found in a propolis sample from La Araucanía Region, respectively.

\section{Biological action on cariogenic bacteria}

The analysis of results shows that a different propolis sample does not have the same inhibitory activity on bacterial growth, but all of them inhibited the mutans streptococci growth. Also, we can see that this activity has a direct relation with the concentration of polyphenols, as determined by the Folin-Ciocalteau method (Table 2). The EEP P001 and P008 from central Chile showed the lowest antimicrobial activity (MIC 6.67 and 8.22, respectively). Similarly, highlighting the propolis P019 and P020, from 
Table 1 - Floral composition of propolis samples studied from central and southern Regions, Chile.

\begin{tabular}{|c|c|c|}
\hline Sample & Region & Predominant species \\
\hline P 001 & Valparaíso & $\begin{array}{l}\text { Trevoa quinquenervia Gill. et Hook. (37\%); Retanilla trinervia Gill. et Hook. (18\%); Colliguaja odorifera Mol. } \\
\text { (9\%); Escallonia pulverulenta Pers. }(6 \%)\end{array}$ \\
\hline P 002 & Metropolitana & $\begin{array}{l}\text { Trevoa quinquenervia Gill. et Hook. (32\%); Brassica rapa L. (18\%); Melilotus indicus L. (13\%); Eucalyptus } \\
\text { globulus Labill. ( } 9 \%)\end{array}$ \\
\hline Р 003 & Metropolitana & $\begin{array}{l}\text { Cardamine o Menonvillea (11\%); Proustia pyrifolia DC (10\%); Quillaja saponaria Mol. (10\%); Eucalytpus } \\
\text { globulus Labill. (9\%) }\end{array}$ \\
\hline Р 004 & Metropolitana & $\begin{array}{l}\text { Colletia or Discaria (11\%); Tricomas de Satureja sp. (11\%); Quillaja saponaria Mol. (11\%); Cardamine or } \\
\text { Menonvillea }(8 \%)\end{array}$ \\
\hline P 005 & Metropolitana & Hypochaeris o Taraxacum (39\%); Plantago sp. (12\%); Eucalyptus sp. (11\%); Cissus striata Ruiz et Pav. (8\%) \\
\hline P 006 & Metropolitana & $\begin{array}{l}\text { Aristotelia chilensis Mol. (9\%); Escallonia sp. (9\%); Medicago sativa L. (9\%); Lithrea caustica Hook. et Arn. } \\
(7 \%) \text {. }\end{array}$ \\
\hline P 007 & Metropolitana & Brassica sp. (19\%); Lotus corniculatus L. (18\%); Azara sp. (13\%); Escallonia sp. (12\%) \\
\hline Р 008 & Metropolitana & $\begin{array}{l}\text { Lithrea caustica Hook. et Arn. (21\%); Trevoa quinquenervia Gill. et Hook. (15\%); Haplopappus glutinosus } \\
\text { Cass. }(9 \%) \text {; Aristotelia chilensis Mol. }(9 \%)\end{array}$ \\
\hline P 009 & Metropolitana & $\begin{array}{l}\text { Aristotelis chilensis Mol. (24\%); Galega officinalis L. (11\%); Retanilla trinervia Gill. et Hook. (9\%); Eucalyp- } \\
\text { tus sp. ( } 5 \%)\end{array}$ \\
\hline P 010 & Metropolitana & $\begin{array}{l}\text { Lithrea caustica Hook. et Arn. (26\%); Quillaja saponaria Mol. (15\%); Escallonia sp. (13\%); Retanilla trinervia } \\
\text { Gill. et Hook. ( } 8 \%)\end{array}$ \\
\hline P 011 & Metropolitana & $\begin{array}{l}\text { Lithrea caustica Hook. et Arn. (23\%); Trevoa quinquenervia Gill. et Hook. (16\%); Baccharis linearis Ruiz et } \\
\text { Pav. (9\%); Brassica sp. (8\%) }\end{array}$ \\
\hline P 012 & $\begin{array}{l}\text { Libertador Bernardo } \\
\text { O'Higgins }\end{array}$ & $\begin{array}{l}\text { Lithrea caustica Hook. et Arn. (19\%); Raphanus sativus L. (13\%); Galega officinalis L. (13\%); Retanilla } \\
\text { trinervia Gill. et Hook. (9\%) }\end{array}$ \\
\hline P 013 & La Araucanía & Lotus uliginosus Schk. (51\%); Eucryphia cordifolia Cav. (18\%); Teucrium sp. (10\%); Sysimbrium sp. (3\%) \\
\hline Р 014 & La Araucanía & $\begin{array}{l}\text { Lotus uliginosus Schk. (36\%); Azara sp. (8\%); Aristotelia chilensis Mol. (7\%); Baccharis linearis Ruiz et Pav. } \\
(2 \%)\end{array}$ \\
\hline P 015 & La Araucanía & $\begin{array}{l}\text { Lotus uliginosus Schk. (84\%); Proustia pyrifolia DC. (5\%); Caldcluvia or Eucryphia (4\%); Baccharis linearis } \\
\text { Ruiz et Pav. (2\%) }\end{array}$ \\
\hline P 016 & La Araucanía & $\begin{array}{l}\text { Lotus uliginosus Schk. (64\%); Buddleja globosa Hope (11\%); Hypochaeris or Taraxacum (5\%); Caldcluvia or } \\
\text { Eucryphia }(5 \%)\end{array}$ \\
\hline P 017 & La Araucanía & $\begin{array}{l}\text { Lotus uliginosus Schk. (85\%); Caldcluvia or Eucryphia (4\%); Hypochaeris or Taraxacum (3\%); Amomyrtus } \\
\text { luma Mol. (1\%) }\end{array}$ \\
\hline P 018 & La Araucanía & $\begin{array}{l}\text { Lotus uliginosus Schk. (81\%); Caldcluvia or Eucryphia (4\%); Proustia pyrifolia DC (2\%); Lotus corniculatus } \\
\text { L. (2\%) }\end{array}$ \\
\hline Р 019 & La Araucanía & $\begin{array}{l}\text { Lotus uliginosus Schk. (39\%); Aextoxicon punctatum Ruiz et Pav. (17\%); Eucalyptus sp. (10\%); Rhamnaceae } \\
(6 \%) \text {. }\end{array}$ \\
\hline P 020 & La Araucanía & $\begin{array}{l}\text { Lotus uliginosus Schk. (61\%); Eucryphia or Caldcluvia (23\%); Luma apiculata (DC.) Burret (5\%); Lotus } \\
\text { corniculatus L. ( } 2 \%)\end{array}$ \\
\hline
\end{tabular}

southern Chile showed the highest antimicrobial activity (MIC 1.94 and 0.90, respectively). When comparing the MIC for $S$. mutans and $S$. sobrinus according to the sample origin we observed for both of them that MIC was lowest with southern propolis $(p=0.011$ and $p=0.007$, respectively). In addition, the statistical analyses showed that propolis from southern Chile (P013 to P020) have the highest polyphenols contents when compared with other regions of our country $(15.288 \pm 3.366 v s .10 .567 \pm 4.764$, $\mathrm{p}=0.026)$.

\section{Discussion}

Among the techniques used to determine the quality of propolis are the botanical identification by microscopic analysis of pollen grains and fragments of leaves or other debris left by the bees during harvesting of plant exudates (Montenegro et al., 2000), and chromatographic tests to confirm the origin of propolis (Burdock, 1998).

The palynological floral origin and composition of propolis depends largely on the plant species present in an area (Peña, 2008). Some investigations suggest common botanical sources and, consequently, similar chemical profiles for large geographical areas. Various authors have concluded that Populus spp. and its hybrids are the main sources of the propolis produced in temperate zones (Europe, North America and non-tropical regions of Asia), and that this type of propolis is characterized by a predominance of flavonoids and phenolic acid esters (Greenaway et al., 1990; Bankova et al., 2000, 2005; Lotti et al., 2010). 
Table 2 - Total polyphenols contents and antibacterial activity of Chilean propolis against mutans streptococci isolated from human oral cavity.

\begin{tabular}{lccc}
\hline Sample & $\begin{array}{c}\text { Concentration } \\
\left(\mathrm{mg} \mathrm{mL}^{-1}\right)\end{array}$ & $\begin{array}{c}\text { S. mutans MIC } \\
\left(\mu \mathrm{gL}^{-1}\right)\end{array}$ & $\begin{array}{c}\text { S. sobrinus MIC } \\
\left(\mu \mathrm{mL}^{-1}\right)\end{array}$ \\
\hline P 001 & 10.7 & 6.67 & 6.67 \\
P 002 & 18.7 & 5.85 & 2.93 \\
P 003 & 11.2 & 3.42 & 3.42 \\
P 004 & 7.5 & 2.45 & 2.45 \\
P 005 & 17.0 & 5.32 & 5.32 \\
P 006 & 3.4 & 2.13 & 2.13 \\
P 007 & 14.5 & 4.52 & 2.26 \\
P 008 & 13.2 & 8.22 & 8.22 \\
P 009 & 8.6 & 2.68 & 2.68 \\
P 010 & 10.9 & 3.41 & 3.41 \\
P 011 & 7.0 & 4.34 & 4.34 \\
P 012 & 4.1 & 2.55 & 2.55 \\
P 013 & 17.0 & 2.66 & 1.33 \\
P 014 & 15.5 & 2.42 & 1.21 \\
P 015 & 21.4 & 3.34 & 3.34 \\
P 016 & 13.1 & 2.05 & 2.05 \\
P 017 & 13.2 & 2.06 & 1.03 \\
P 018 & 18.1 & 2.82 & 1.41 \\
P 019 & 12.4 & 1.94 & 1.94 \\
P 020 & 11.6 & 0.90 & 0.90 \\
\hline
\end{tabular}

MIC, Minimum Inhibitory Concentration.
Table 4 - Quantification of polyphenolic compounds detected in the propolis from La Araucanía Region.

\begin{tabular}{lc}
\hline Compounds & Sample P013 \\
\hline Caffeic acid & 12.3 \\
Resveratrol & 0 \\
Quercetin & 75.2 \\
Apigenin & 31.4 \\
Pinocembrin & 1006.4 \\
Galangin & 75.5 \\
CAPE & 532.6 \\
\hline
\end{tabular}

CAPE, Caffeic acid phenetyl ester; Values expressed as $\mathrm{mg} \mathrm{mL}^{-1}$.

In the tropics, poplars are seldom cultivated, so alternative plants are sources of propolis resin, as occur in Venezuela with the flowers of Clusia minor (Tomas-Barberán et al., 1993) and of Clusia rosea in Cuba (Cuesta Rubio et al., 1999). In both cases, flavonoids are minor propolis constituents, and the major compounds are polyprenylated benzophenones. In Brazil, the propolis produced according to botanical origin and chemical composition is from Hyptis divaricata, Baccharis dracunculifolia and Populus nigra (Salatino et al., 2005).

In our study highlights the low penetration of plant structure from introduced plants that are abundant in central and Southern Chile, and recognized producers of resins for the production of propolis, such as Eucalyptus, Pynus, and Populus, the latter absent in all samples.

Table 3 - Polyphenols detected in propolis samples from central and southern Regions of Chile by HPLC analysis.

\begin{tabular}{|c|c|c|c|c|c|c|c|c|c|}
\hline Sample & Caffeic acid & Resveratrol & Myricetin & Quercetin & Kaempferol & Apigenin & Pinocembrin & CAPE & Galangin \\
\hline P 001 & + & n.d. & n.d. & + & + & + & + & + & + \\
\hline P 002 & + & n.d. & + & + & + & + & + & + & + \\
\hline P 003 & + & + & + & + & + & + & + & + & + \\
\hline Р 004 & n.d. & n.d. & + & + & + & + & + & + & + \\
\hline P 005 & + & n.d. & + & n.d. & + & + & + & n.d. & + \\
\hline Р 006 & + & n.d. & + & + & + & + & + & + & + \\
\hline P 007 & + & n.d. & + & n.d. & n.d. & + & + & + & + \\
\hline P 008 & + & + & + & + & + & + & + & + & + \\
\hline Р 009 & + & n.d. & + & n.d. & + & n.d. & + & + & + \\
\hline P 010 & + & + & + & + & + & + & + & + & + \\
\hline P 011 & + & + & + & + & + & + & + & + & + \\
\hline P 012 & + & n.d. & + & n.d. & + & + & + & + & + \\
\hline Р 013 & + & n.d. & + & + & + & + & + & + & + \\
\hline Р 014 & + & n.d. & + & n.d. & + & + & + & + & + \\
\hline P 015 & + & n.d. & + & + & + & + & + & + & + \\
\hline P 016 & + & n.d. & + & + & + & + & + & + & + \\
\hline P 017 & + & n.d. & + & + & + & + & + & + & + \\
\hline P 018 & + & n.d. & + & + & + & + & + & + & + \\
\hline Р 019 & + & n.d. & + & + & n.d. & + & + & n.d. & + \\
\hline P 020 & + & n.d. & n.d. & + & n.d. & + & + & + & + \\
\hline
\end{tabular}

CAPE, Caffeic acid phenetyl ester; +, indicates presence; n.d., not detected. 


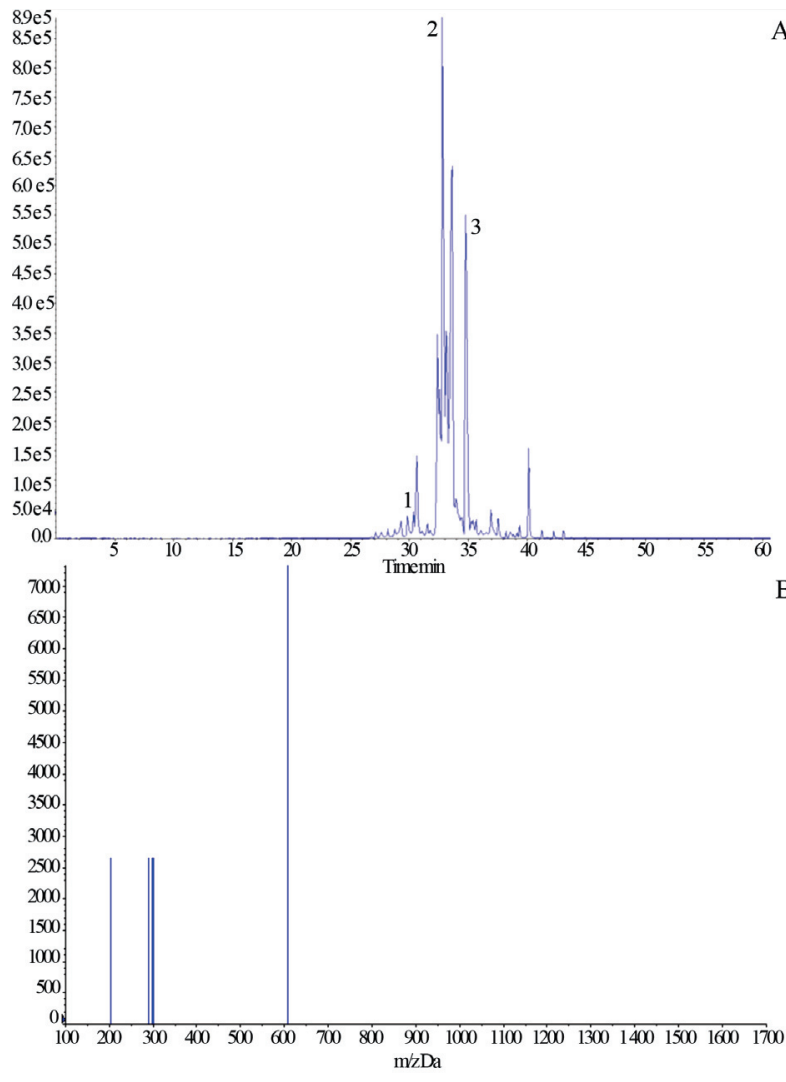

Figure 1 - A. Chromatogram of flavonols from a propolis sample: 1) Rutin (29.25), 2) myricetin (32.82) and quercetin (32.89), 3) kaempferol (34.79). B. Negative ions HPLC-MS mass spectra of rutin identified in propolis sample P013.

Koenig (1995) and Montenegro et al. (2001a) described Salix humboldtiana species and E. globulus between endemic and introduced plants, respectively, as the most frequent, found in an apiary network of central Chile.

The botanical origin of propolis from central Chile has been determined previously by micro-morphological analysis of pollen and epidermal attachments (Montenegro et al., 2001b). However, spectrophotometer methods, including the Folin Ciocalteu are among the most widely used because there are some authors who consider inaccurate this identification system, applied to propolis, because the pollen is produced in plant anatomical areas different from where are extracted propolis resins, such as buds and wounds of plants and trees.

Studies of the biological activities of propolis should thus be complemented by information about chemical composition and botanical source of the sample, or at least mention it geographical origin, so that these biological activities can be linked to the specific type of propolis (Koo et al., 1999).

The results of chemical characterization of propolis samples by HPLC showed varying concentrations of caffeic acid, myricetin, quercetin, kaempferol, apigenin, pinocembrin, CAPE and galangin. The chemical character-

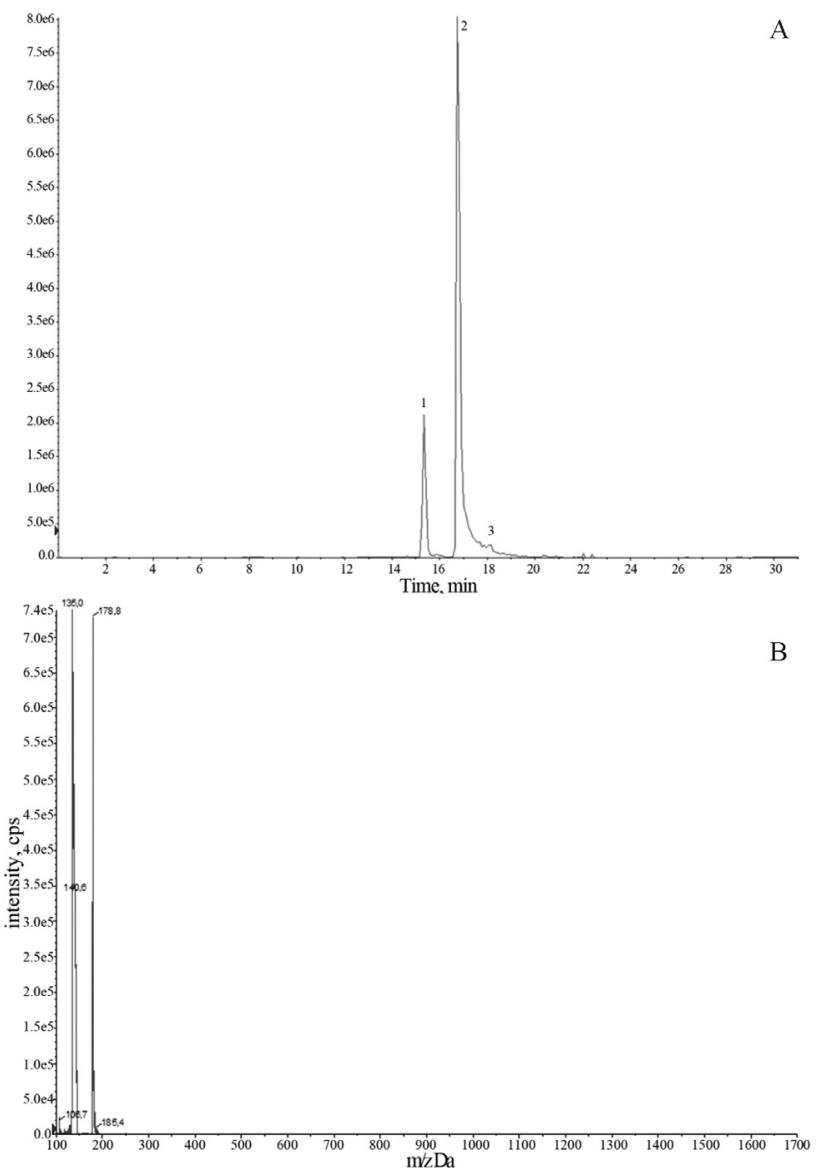

Figure 2 - A. Chromatogram of phenolic acids from a propolis sample: 1) Caffeic acid (15.45), 2) coumaric acid (16.78);3) and 3) coumaric acid derivatives (20.345). B. Negative ions HPLC-MS mass spectra of caffeic acid identified in propolis sample P013.

ization by HPLC/MS, which was carried out with a screening of flavonols: quercetin, myricetin, kaempferol and rutine, evidenced the presence of the first three compounds that have already been described in these propolis with conventional HPLC (Herrera et al., 2009; Saavedra et al., 2011). In addition, it was possible to detect the presence of coumaric acid, caffeic acid and caffeic acid phenyl ester.

Polyphenols detected in propolis samples from central and southern Regions of Chile by HPLC analysis demonstrated the presence, in all samples, of pinocembrin and galangin. The quantification of polyphenols showed that pinocembrin is the main compound present in Chilean propolis, being the propolis from southern Chile which contained in greater proportion this compound. These results are similar to that obtained for Agüero et al. (2010) who observed that galangin and pinocembrin are the main compounds of an Argentinean propolis. Also, Gardana et $a l$. (2007) demonstrated that pinocembrin was one of the most abundant in propolis samples from several countries, including seven samples from Chile. They also highlight the higher proportion of total flavonoids and phenolic acid 
content in raw samples of propolis from different geographic areas, similarly to our results.

In other report Koru et al. (2007) evaluated the chemical composition of propolis samples from different geographic origins using chromatographic techniques and mass spectrometry, and showed that the main components were the flavonoids pinobanksin, quercetin, naringenin, galangin, chrysin and aromatic acids such as caffeic acid.

Among other research, Castro et al. (2009) identified a new bioactive compound of propolis, which would be responsible for the antimicrobial activity of propolis called type 6 , originally from the state of Bahia (Brazil). The compound was identified by HPLC-MS, as belonging to the group of benzophenones (aromatic ketones). In addition, the authors showed that this compound has antibacterial action on several strains of cariogenic streptococci. They evaluated fractions of propolis type 6 , and found that only certain portions of it showed antimicrobial activity. It was noted that the fraction containing fatty acid has antibacterial action. In contrast, the fraction containing benzophenone has antibacterial effect on Staphylococcus aureus and Streptococcus mutans.

The use of agents that reduce the viability but also control the colonization on the tooth surface by inhibiting the biofilm formation could be a promising approach for the prevention of dental caries. In this context, we examined the potential activity of propolis extracts against $S$. mutans and S. sobrinus. In this study, we observed differences in the action demonstrated by each of the propolis evaluated. This difference in the minimum concentration that inhibits visible growth of bacteria could be due to differences in chemical composition of this propolis, which depends on several factors including geographic location, botanical origin and the season time of collection, according to the results obtained by Sonmez et al. (2005).

Koru et al. (2007) evaluated the effect of propolis on certain oral pathogens as Prevotella oralis, Lactobacillus acidophilus, Veillonella parvula, Actinomyces naeslundii, among others. They showed that propolis was most effective on Gram-positive anaerobic bacteria than Gram-negative bacteria. This result is important, considering that mutans streptococci (main microorganisms associated with the development of caries) are Gram-positive. The authors conclude that because of increasing antimicrobial resistance, propolis could be considered in the treatment of diseases affecting the oral cavity.

Also, Velázquez et al. (2007) showed that Mexican propolis have antibacterial and antioxidant activity. The authors attribute this to the presence of flavonoids, especially the presence of CAPE (caffeic acid phenethyl ester), the second compound in abundance present in the Chilean propolis samples evaluated.

Previous reports with Chilean propolis have highlighted the inhibition of Candida spp isolated from the oral cavity of removable dentures users, and the cariogenic bac- teria Lactobacillus fermentum (Herrera et al., 2009; Saavedra et al., 2011), and also the inhibition of mutans streptococci group with honeys from Southern Chile (Salazar et al., 2009).

Chaillou and Nazareno (2009) demonstrated that the bioactivity of Argentinean propolis sample from Santiago del Estero is assigned to pinocembrin, present in high concentration in all the samples studied. Also, they found a good correlation between the antimicrobial activity and pinocembrin content for $S$. aureus.

While it is well recognized the antimicrobial action of propolis, the mechanisms by which it exerts its antimicrobial effect remain unclear. It has been reported that some components present in extracts of propolis such as flavonoids (quercetin, galangin, pinocembrin) and caffeic acid, benzoic acid, and cinnamic acid probably act at a site on the membrane or cell wall, causing structural and functional damage (Kosalec et al., 2005; Scazzocchio et al., 2006). Others suggest that the $\beta$ ring structure of flavonoids may play a role in integration or hydrogen bonding of the bases, which would explain the action on the synthesis of DNA and RNA. Also, it is proposed the inhibition of DNA gyrase and ATPase by compounds found in propolis. Likewise, it has been shown a decrease in bacterial membrane fluidity, increased permeability and membrane potential dissipation (Cushnie and Lamb, 2005). A recent study showed that the EEP completely abolished virulence factor coagulase enzyme of Staphylococcus aureus and demonstrated a preventive effect dose-dependent on biofilm formation (Scazzocchio et al., 2006).

\section{Conclusion}

The botanical analysis and chemical composition of 20 propolis samples has been determined by HPLC and HPLC-Ms analysis on the basis of 9 standards of phenolic acids and flavonoids. Different propolis sample does not have the same inhibitory activity on bacterial growth, but all of them inhibited the mutans streptococci growth. Also, we can see that this activity has a direct relation with the concentration of polyphenols, and propolis from southern Chile have the highest polyphenols content when compared with other regions of our country. The higher concentrations of pinocembrin suggest that this flavonoid could be responsible by the bioactivity against cariogenic bacteria studied.

However, given the wide range of biological activity exhibited by propolis and the high variability and complexity of their chemical composition, it becomes increasingly evident the need of standardization procedures, where we combine both the determination of botanical and geographical origin, as the chemical characterization of the extracts. Research conducted to date, describes a promising effectiveness of propolis in the prevention of caries and other diseases of the oral cavity. Nevertheless, it is necessary to 
develop studies to identify and understand the therapeutic targets or mechanisms of molecular action of the various compounds present on them.

\section{Acknowledgments}

We gratefully acknowledge Rodrigo Pizarro and Gabriela Valdebenito for technical help in palynological and HPLC-MS analysis, respectively. This study was supported by grants from Dirección de Investigación y Desarrollo (DIUFRO DI10-0031, DIUDRO DI09-1007, DIUFRO DI12-1002 and DIUFRO DI12-2013), Universidad de La Frontera, and CONICYT (FONDEF D05I-10021), Chile.

\section{References}

Agüero MB, González M, Lima B, Svetaz L, Sánchez M, Zacchino S, Egly Feresin G, Schmeda-Hirschmann G, Palermo J, Wunderlin D, Tapia A (2010) Argentinean Propolis from Zuccagnia punctata Cav. (Caesalpinieae) Exudates: Phytochemical Chracterization and Antifungal Activity. J Agric Food Chem 58:194-201.

Bankova V, Christov R, Kujumgiev A, Marcucci MC, Popov S (1995) Chemical composition and antibacterial activity of Brazilian propolis. Z Naturforsch 50:167-172.

Bankova V, De Castro L, Marcucci MC (2000) Propolis recent advances in chemistry and plant origin. Apidologie 31:3-15.

Bankova V (2005) Chemical diversity of propolis and the problem of standardization. J Ethnopharmacol 100:114-117.

Borrelli F, Maffia P, Pinto L, Ianaro A, Russo A, Capasso F, Ialenti A (2002) Phytochemical compounds involved in the anti-inflammatory effect of propolis extract. Fitoterapia 73:S53-S63.

Burdock GA (1998) Review of the biological properties and toxicity of bee propolis (propolis). Food Chem Toxicol 36:347-363.

Castro ML, do Nascimento AM, Ikegaki M, Costa-Neto CM, Alencar SM, Rosalen PL (2009) Identification of a bioactive compound isolated from Brazilian propolis type 6. Bioorg Med Chem 17:5332-5335.

Chaillou L, Nazareno M (2009) Chemical variability in propolis from Santiago del Estero, Argentina, related to the arboreal environment as the sources of resins. J Sci Food Agric 88:978-983.

Chen CN, Weng MS, Wu CL, Lin JK (2004) Comparison of radical scavenging activity, cytotoxic effects and apoptosis induction in human melanoma cells by Taiwanese propolis from different sources. Evid base Compl Alternative Med 1:175-185.

Clinical and Laboratory Standards Institute (CLSI) (2007) Methods for Antimicrobial Susceptibility Testing of Anaerobic Bacteria; Approved Standard. Seven Edition. CLSI document M11-A7. Clinical and Laboratory Standards Institute, Wayne, PA, USA.

Cuesta Rubio O, Cuellar A, Rojas N, Velez Castro H, Rastrelli L, Aquino R (1999) A polyisoprenylated benzophenone from Cuban Propolis. J Nat Prod 62:1013-1015.

Cushnie T, Lamb J (2005) Antimicrobial activity of flavonoids. Int J Antimicrob Agents 26:343-356.

Dye BA, Tan S, Smith V, Lewis BG, Barker LK, Thornton-Evans G, Eke PI, Beltrán-Aguilar ED, Horowitz AM, Li CH (2007)
Trends in oral health status: United States, 1998-1994 and 1999-2004. Vital Health Stat 11:248, 1-92.

Duarte S, Rosalen PL, Hayacibara MF, Cury JA, Bowen WH, Marquis RE, Rehder VL, Sartoratto A, Ikegaki M, Koo H (2006) The influence of a novel propolis on mutans streptococci biofilms and caries development in rats. Arch Oral Biol 51:15-22.

Erdtman G (1986) Pollen Morphology and Plant Taxonomy. E.J. Brill Press, Leiden. The Netherlands.

Gardana C, Scaglianti M, Pietta P, Simonnetti P (2007) Analysis of the polyphenolic fraction of propolis from different sources by liquid chromatography-tandem mass spectrometry. J Pharm Biomed Anal 45:390-399.

Greenaway W, Scaysbrook T, Whately FR (1990) The composition and plant origin of propolis: a report of work at Oxford. Bee World 71:107-118.

Hamilton-Miller JM (2001) Anti-cariogenic properties of tea ( $\mathrm{Ca}$ mellia sinensis). J Med Microbiol 50:299-302.

Herrera C, Alvear M, Barrientos L, Montenegro G, Salazar LA (2009) Actividad fungicida de seis extractos de propóleos comerciales chilenos sobre Candida spp. Cien Inv Agr 37:75-84.

Heusser JC (1971) Pollen and Spores of Chile. Modern Types of the Pteridophyta, Gymnospermae, and Angiospermae. Tucson, USA. The University of Arizona Press.

Koenig B (1995) Plant sources of propolis. Bee World 66:136139.

Koo H, Rosalen PL, Cury JA, Park YK, Ikegak M, Sattler A (1999) Effect of Apis mellifera propolis from two Brazilian regions on caries development in desalivated rats. Caries Res 33:393-400.

Koo H, Rosalen PL, Cury JA, Ambrosano GM, Murata RM, Yatsuda R, Ikegaki M, Alencar SM, Park YK (2000) Effect of a new variety of Apis mellifera propolis on mutans Streptococci. Curr Microbiol 41:192-196.

Koo H, Rosalen PL, Cury JA, Park YK, Bowen WH (2002a) Effects of compounds found in propolis on Streptococcus mutans growth and on glucosyltransferase activity. Antimicrob Agents Chemother 46:1302-1309.

Koo H, Pearson SK, Scott-Anne K, Abranches J, Cury JA, Rosalen PL, Park YK, Marquis RE, Bowen WH (2002b) Effects of apigenin and tt-farnesol on glucosyltransferase activity, biofilm viability and caries development in rats. Oral Microbiol Immunol 17:337-343.

Koru O, Toksoy F, Acikel CH, Tunca YM, Baysallar M, Uskudar Guclu A, Akca E, Ozkok Tuylu A, Sorkun K, Tanyuksel M, Salih B (2007) In vitro antimicrobial activity of propolis samples from different geographical origins against certain oral pathogens. Anaerobe 13:140-145.

Kosalec I, Pepelnijak S, Bakmaz M, Wladimir-Knezevic V (2005) Flavonoid analysis and antimicrobial activity of commercially available propolis products. Acta Pharm 55:423-430.

Kujumgiev A, Tsvetkova I, Sekledjieva Y, Bankova V, Christov R, Popov S (1999) Antibacterial, antifungal and antiviral activity of propolis of different geographic origin. J Ethnopharmacol 64:235-240.

Limsong J, Benjavongkulchai E, Kuvatanasuchati J (2004) Inhibitory effect of some herbal extracts on adherence of Streptococcus mutans. J Ethnopharmacol 92:281-289.

Loesche WJ (1986) Role of Streptococcus mutans in human dental decay. Microbiol Rev 50:353-380. 
Lotti C, Campo Fernández M, Piccinelli AL, Cuesta-Rubio O, Márquez Hernández I, Rastrelli L (2010) Chemical constituents of red Mexican propolis. J Agric Food Chem 58:22092213.

Montenegro G (1984) Atlas de anatomía de especies vegetales autóctonas de la Zona Central. Ediciones Universidad Catolica de Chile, Santiago, Chile.

Montenegro G, Gómez M, Ávila G (1992) Importancia relativa de especies cuyo polen es utilizado por Apis mellifera en el área de la Reserva Nacional Los Ruiles, VII Región de Chile. Acta Bot Malacit 17:167-174.

Montenegro G, Timmermann BN, Peña RC, Mujica A, Avila G (2000) Pollen grains and vegetative structures in propolis as indicators of potencial reactions in Chilean plants. Phyton 66:15-23.

Montenegro G, Peña RC, Mujica A, Pizarro R (2001a) Botanical resources for propolis in an apiary network in central Chile. Phyton 191-201.

Montenegro G, Avila G, Peña RC (2001b) Botanical origin and seasonal production of propolis in hives of Central Chile. Bol Bot Univ Sao Paulo 19:1-6.

Orsi RO, Sforcin JM, Funari SR, Bankova V (2005) Effects of Brazilian and Bulgarian propolis on bactericidal activity of macrophages against Salmonella typhimurium. Int Immunopharmacol 5:359-368.

Osawa K, Miyazaki K, Shimura S, Okuda J, Matsumoto M, Ooshima T (2001) Identification of cariostatic substances in the cacao bean husk: their anti-glucosyltransferase and antibacterial activities. J Dent Res 80:2000-2004.

Peña C (2008) Estandarización en propóleos: antecedentes químicos y biológicos. Cie. Inv. Agr 35:17-26.

Piccinelli AL, Fernández MC, Cuesta-Rubio O, Hernández IM, De Simone F, Rastrelli L (2005) Isoflavonoids isolated from Cuban propolis. J Agric Food Chem 53:9010-9016.

Russo A, Longo R, Vanella A (2002) Antioxidant activity of propolis: role of caffeic acid phenethyl ester and galangin. Fitoterapia 73:21-29.

Saavedra N, Barrientos L, Herrera C, Alvear M, Montenegro G, Salazar LA (2011) Effect of Chilean propolis on cariogenic Lactobacillus fermentum bacteria. Cien Inv Agr 38:117125.

Salatino A, Teixeira EW, Negri G, Message D (2005) Origin and chemical variation of Brazilian propolis. Evid base Compl Alternative Med 2:33-38.

Salazar LA, Vásquez C, Almuna A, Oporto G, Santana R, Herrera C, Sanhueza A (2008) Detección Molecular de Estreptococos Cariogénicos en Saliva. Int J Morphol 26:951-958.
Salazar LA, Medina F, Donoso F, Barrientos L, Sanhueza A 2009 Acción antimicrobiana in vitro de la miel de abejas sobre los microorganismos cariogénicos estreptococos del grupo mutans. Int J Morphol 27:77-82.

Scazzocchio F, D’Auria FD, Alessandrini D, Pantanella F (2006) Multifactorial aspects of antimicrobial activity of propolis. Microbiol Re. 161:327-333.

Sforcin JM, Fernándes Jr A, Lopes CA, Bankova V, Funari SR (2000) Seasonal effect on Brazilian propolis antibacterial activity. J Ethnopharmacol 73:243-249.

Singleton VL, Orthofer R, Lamuela-Raventos RM (1999) Analysis of total phenols and other oxidation substrates and antioxidants by means of Folin-Ciocalteu reagent. Methods Enzymol 299:152-178.

Smith DJ (2002) Dental caries vaccines: Prospects and concerns. Crit Rev Oral Biol Med 13:335-349.

Sonmez S, Kirilmaz L, Yucesoy M, Yucel B, Yilmaz B (2005) The effect of bee propolis on oral pathogens and human gingival fibroblasts. J Ethnopharmacol 102:371-376.

Steinberg D, Feldman M, Ofek I, Weiss EI (2004) Effect of a high-molecular-weight component of cranberry on constituents of dental biofilm. J Antimicrob Chemother 54:86-89.

Tomas-Barberán FA, Garcia-Viguera C, Vitolivier P, Ferreres F, Tomás-Lorente F (1993) Phytochemical evidence for the botanical origin of tropical propolis from Venezuela. Phytochemistry 34:191-196.

Tosi EA, Ré E, Ortega ME, Cazzoli AF (2007) Food preservative based on propolis: bacteriostatic activity of propolis polyphenols and flavonoids upon Escherichia coli. Food Chem 104:1025-1029.

Valencia D, Alday E, Robles-Zepeda R, Garibay-Escobar A, Galvez-Ruiz JC, Salas-Reyes M, Jiménez-Estrada M, Velázquez-Contreras E, Hernández J, Velázquez C (2012) Seasonal effect on chemical composition and biological activities of Sonoran propolis. Food Chem 131:645-651.

Velázquez C, Navarro M, Acosta A, Angulo A, Domínguez Z, Robles R, Robles-Zepeda R, Lugo E, Goycoolea FM, Velázquez EF, Astiazaran H, Hernández J (2007) Antibacterial and free-radical scavenging activities of Sonoran propolis. J Appl Microbiol 103:1747-1756.

Xiao J, Zuo Y, Liu Y, Li J, Hão Y, Zhou X (2007) Effects of Nidus vespae extract and chemical fractions on glucosyltransferases, adherence and biofilm formation of Streptococcus mutans. Arch Oral Biol 52:869-875.

All the content of the journal, except where otherwise noted, is licensed under a Creative Commons License CC BY-NC. 